\section{NOTES ON MAMMALIAN FAUNA OF RAJASTHAN}

\author{
Subhasini Sharma ${ }^{1}$, Satish Kumar Sharma ${ }^{2}$ and \\ Shweta Sharma ${ }^{1}$
}

${ }^{1}$ Lab No. 9, Department of Zoology, University of Rajasthan, Jaipur, Rajasthan 302004, India.

${ }^{2}$ Range Forest Officer (Nahargarh Biological Park) 2, Suresh Nagar, Durgapura, Jaipur, Rajasthan 302017, India.

Rajasthan $\left(23^{\circ} 3^{\prime}-30^{\circ} 12^{\prime} \mathrm{N}\right.$ and $\left.69^{\circ} 30^{\prime}-78^{\circ} 17^{\prime} \mathrm{E}\right)$ is the second largest state $\left(3,42,274 \mathrm{~km}^{2}\right)$ of the country. The Aravalli is the principal and dominant mountain range running diagonally across the state from Delhi in the northeast extending southwest to the plains of Gujarat for a length of about $692 \mathrm{~km}$. A considerably large portion of the state to the west of the Aravalli is desert (rainfall of $100-400 \mathrm{~mm}$ ). The region east of the Aravalli is relatively fertile. The Aravalli Hills of northeastern, southwestern and southern Rajasthan are covered with deciduous forest, which turn lush green during monsoon. Mt. Abu however, has semievergreen forest owing to its towering height and high rainfall.

Due to variable habitats and climate, Rajasthan had rich mammalian fauna before independence. The increasing biotic interference after independence has not only reduced mammalian fauna, but even a change in the distribution ranges have been noticed. Hence, in this paper the present status of mammalian diversity in Rajasthan has been discussed. Faunistic surveys made by earlier workers in Rajasthan were consulted (Bates et al., 1994a,b,c; Divyabhanusingh, 1986; Joshi, 1984; Prakash, 1994, 1995; Rahmani, 1991; Rana, 1991; Rice, 1991; Sankaran, 1992; Sankhala, 1979; Saxena, 1975; Singh \& Sharma, 1985; Singh, 1985; Tehsin, 1980, 1987; Tripathi et al., 1985; Wada, 1984). The two national parks and most of the wildlife sanctuaries as well as rural and tribal pockets of Rajasthan were visited to collect latest information on wild mammals. Their census records were procured from the Rajasthan State Forest Department, Jaipur (Anonymous, 2001). On the basis of their occurrence, the wild mammals are classified into five categories viz., common, rare, recently reported, locally extinct and probable future invaders. Scientific names and common names are after Nameer (1998).

In the post independence era, the principal factors adversely affecting wildlife in the state are population explosion (330\%; based on 1951 and 1998 census, Source: census reports of 1951 and 1998) and increase in urbanisation and industrialization (510\%; based on 1975 and 1998 data; Gupta, 1987; Anonymous, 1999a). Additional land required for all these anthropogenic activities has resulted in shrinking forest cover of the state (66\%; based on forest cover of 1993 and 1999; Anonymous, 1999a,b). The rise in domestic animal populations (59\%; based on livestock data of 1962 and 1997; Anonymous, 1964, 1999a) is also a threat to wildlife, as they often share same habitats for grazing. The present status of wild mammals of Rajasthan has been discussed below in detail.

\section{Common mammals}

Majority of the commonly occurring mammals in Rajasthan are found in protected areas (Table 1). Macaca mulatta occurs in eastern and southeastern Rajasthan (Wada, 1984; Tehsin, 1950; Sankaran, 1992). Rodents are distributed throughout the state except for Hystrix indica which is declining fast because of its use as food during festivals by tribals and nomads. Striped Palm Squirrel (Funambulus pennanti) and Lepus nigricollis are found all through Rajasthan, whereas Large Flying Squirrel is confined to the Sitamata Sanctuary, Chittoragarh (Tehsin, 1980). Gazella is mainly concentrated in the Thar Desert near Bishnoi villages. Sus scrofa once found all over Rajasthan now occurs only in the protected areas. It is known to raid the agricultural fields in the vicinity of protected areas. Earlier, the state rulers protected boars because they were favorite game animals, but recently farmers do not favour this animal because they are very destructive to crops. Boars are now rapidly invading command area of Indira Gandhi Nahar Pariyojna (IGNP) in the Thar (Prakash, 1994). The Blue Bull Boselaphus tragocamelus flourishing in the plains of Rajasthan is now rapidly migrating in IGNP area and is also becoming a serious menace to crops. It moves in herds of four to 10 or even more individuals (Prakash, 1995). Cervus unicolor is mainly concentrated in the dense forest areas in southern parts of the state. Both Common Mangoose (Herpestes edwardsi) and Small Indian Mangoose (Herpestes auropunctatus) are still found abundantly in the fields. Herpestes smithi is present in wooded areas of Rajasthan especially in the forests of Nahargarh, Jamwa, Ramgarh, Siriska and Ranthambhore.

\section{Rare mammals}

As per 1901 record, the total tiger population in the state was 3500 , now it is reduced to 66. Once "Nahari ka Naka" - a water hole in Nahargarh, Jaipur was a home to tigers and other large cats (Joshi, 1984). It is now restricted to the dense deciduous forest of Sariska (Alwar), Ranthambhore, Karauli and Bundi. The population of Jungle Cat Felis chaus has also declined considerably as compared to the past (Table 2). Caracal once commonly found near Jaipur is now extremely rare (Sankhala, 1979). Melursus ursinus (Sloth Bear) once found most commonly in the wooded part of Rajasthan is now confined to Ranthambhore, Karauli, Kumbhalgarh, Mt. Abu and Phulwari 
Table 1. Common mammals of Rajasthan

\begin{tabular}{|c|c|c|c|c|}
\hline Name of species & Common name & Present status & $\begin{array}{l}\text { Census } \\
1999 \\
\end{array}$ & 2000 \\
\hline Macaca mulatta & Rhesus Macaque & Eastern and southeastern Rajasthan & N.A & N.A \\
\hline Semnopithecus entellus & Hanuman Langur & Whole Rajasthan except very arid western part & N.A & 30814 \\
\hline Panthera pardus & Leopard & Whole Rajasthan except desert & 111 & 405 \\
\hline Felis chaus & Jungle Cat & Whole Rajasthan & N.A & N.A \\
\hline Felis sylvestris & Desert Cat & Barmer, Bikaner, Jaisalmer, Pali Nagaur & $800^{*}$ & - \\
\hline Paradoxurus hermaphroditus & Toddy Cat & Whole Rajasthan & N.A & N.A \\
\hline Herpestes javanicus & Small Indian Mangoose & Eastern and western Rajasthan & N.A. & N.A \\
\hline Herpestes brachyurus & Brown Mangoose & Southern Rajasthan & N.A & N.A \\
\hline Herpestes smithii & Ruddy Mangoose & Wooded areas of Rajasthan & N.A & N.A \\
\hline Herpestes edwardsii & Common Mangoose & Whole Rajasthan & N.A & N.A \\
\hline Hyaenahyaena & Striped Hyaena & Whole Rajasthan & 1489 & 1069 \\
\hline Canis aureus & Jackal & Whole Rajasthan & 12445 & 13436 \\
\hline Melursus ursinus & Sloth Bear & Ranthambhore, Karauli, southern Rajasthan and Pali & 480 & 325 \\
\hline Suncus murinus & Grey Musk Shrew & Whole Rajasthan & N.A & N.A \\
\hline Pteropus giganteus & Flying Fox & Whole Rajasthan except external desert district & N.A & 1113 \\
\hline Cynopterus sphinx & Short-nosed Fruit Bat & $\begin{array}{l}\text { Wooded districts of Rajasthan viz. Banswara, Bundi. } \\
\text { Bharatpur, Jhalawar, Udaipur }\end{array}$ & N.A & N.A \\
\hline Funambulus pennantii & Five Striped Palm Squirrel & Whole Rajasthan & N.A & N.A \\
\hline Tatera indica & Indian Gerbile & Whole Rajasthan & N.A & N.A \\
\hline Meriones hurrianae & Indian Desert Gerbile & Sandy tract of State & N.A & N.A \\
\hline Rattus rattus & House Rat & Whole Rajasthan & N.A & N.A \\
\hline Vandeleuria oleracea & Long-tailed Tree Mouse & Whole Rajasthan & N.A & N.A \\
\hline Cremnomys cutchicus & Kutchch Rat & Southern Rajasthan & N.A & N.A \\
\hline Millardia meltada & Metad & Thar desert & N.A & N.A \\
\hline Mus musculus & House Mouse & Whole Rajasthan & N.A & N.A \\
\hline Mus booduga & Indian Field Mouse & Whole Rajasthan & N.A & N.A \\
\hline Mus phillipsi & Phillips's Mouse & Southern Rajasthan & N.A & N.A \\
\hline Golunda ellioti & Indian Bush Rat & Whole Rajasthan & N.A & N.A \\
\hline Bandicota bengalensis & Indian Mole Rat & Whole Rajasthan & N.A & N.A \\
\hline Hystrix indica & Indian Porcupine & Whole Rajasthan & N.A & N.A \\
\hline Gazella bennettii & Chinkara & Whole Rajasthan especially western Rajasthan & 4121 & 5300 \\
\hline Antilope cervicapra & Black Buck & $\begin{array}{l}\text { Alwar, Bikaner, Tonk Sirohi, Jalore,Sikar,Jhunihunu } \\
\text { Jodhpur, Nagaur, Churu and Pali }\end{array}$ & 1629 & 1831 \\
\hline Boselaphus tragocamelus & Nilgai & Whole Rajasthan & N.A & N.A \\
\hline Cervus unicolor & Sambhar & Dense forest areas of state, but decreasing in southern part & N.A & N.A \\
\hline Axis axis & Chital & Whole Rajasthan & 13862 & $367^{\star *}$ \\
\hline Sus scrofa & Indian Wild Boar & Whole Rajasthan, gradually appearing in IGNP area also & N.A** & 367 \\
\hline
\end{tabular}

IGNP* = Indira Gandhi Nahar Pariyogna

Wildlife Sanctuary. It is also present in Kota region. Manis crassicaudata (Ant Eater) distributed widely earlier is now rare. During 1996, one specimen was caught in Kalkana Village near Nasirabad in Ajmer District (Sharma, 1995). On 23-24 April 1986 three wild dogs (Cuon alpinus) were seen in Sariska (Divyabhanusingh,1986). Perhaps this species is now no more in Sariska, though very much present in Ranthambhore.

\section{Recently reported mammals}

This category includes five mammals. Prionailurus rubiginosus is reported only from Udaipur and Sariska, while Prionailurus viverrinus from Alwar, Bharatpur, Pali and Udaipur. Petaurista petaurista philipinus is known only from Sitamata Sanctuary and Moschiola meminna from southern Rajasthan. A small population of Gangetic Dolphins Platanista gangetica is present in Chambal River in Karauli region of Rajasthan (Singh \& Sharma, 1985).

\section{Locally extinct mammals}

Axis porcinus, once reported from Keoladeo National Park, Bharatpur, is not recorded from the area in the recent past (Saxena, 1975). 
Table 2. Rare mammals of Rajasthan

\begin{tabular}{|c|c|c|c|c|}
\hline \multirow[t]{2}{*}{ Name of species } & \multirow[t]{2}{*}{ Common name } & \multirow[t]{2}{*}{ Present status } & \multicolumn{2}{|c|}{ Census } \\
\hline & & & 1999 & 2000 \\
\hline Panthera tigris & Bengal tiger & Sariska (Alwar), Ranthambhore (Sawai Madhopur), Karauli and Bundi & 408 & 405 \\
\hline Caracal caracal & Caracal & Ajmer, Pali, Ranthambhore (Sawai Madhopur), Sariska (Alwar) & N.A & N.A \\
\hline Canis lupus & Wolf & Desert part of Rajasthan, Kumbhalgarh (Rajasamand), Jaipur & 273 & 213 \\
\hline Vulpes vulpes & Red Fox & Whole Rajasthan & 4290 & 5147 \\
\hline Vulpes bengalensis & Indian Fox & Whole Rajasthan & N.A & N.A \\
\hline Lutrogale perspicillata & Smooth Indian Otter & Perennial big water bodies of the State & N.A & N.A \\
\hline Tetracerus quadricomis & Four-horned Antelope & Jalore, Pali, Udaipur, Ajmer, Dholpur, Chittorgarh & 12 & \\
\hline Manis crassicaudata & Indian Pangolin & Whole Rajasthan & N.A & N.A \\
\hline
\end{tabular}

\section{Probable future invaders}

This includes wild animals not reported earlier but is likely to be present in Rajasthan. Paraechinus hypomelas confined to Pakistan may occur in the border areas. With increased irrigation in the arid areas, Bandicota indica are likely to enter in the irrigated pockets along Indira Gandhi Canal. Similarly, with increased availability of water and vegetation cover, Nilgai and Wild Boar are not only appearing in IGNP area but they are gradually proceeding ahead along the canal (Rana, 1991).

\section{Acknowledgements}

The first author is grateful to SAP Coordinator and the Head, Department of Zoology, University of Rajasthan, Jaipur for providing necessary facilities.

\section{References}

Anonymous (1964). Statistical Abstract, Rajasthan, Directorate of Economics and Statistics, Rajasthan, Jaipur.

Anonymous (1999a). Source: Basic Statistics 1999: Rajasthan, Directorate of Economics \& Statistics, Rajasthan, Jaipur.

Anonymous (1999b). State Forest Report, Forest Survey of India, Ministry of Environment and Forest, New Delhi.

Anonymous (2001). Vanya Jeev Sarankshan aibam Jan Sahbhagita (Conservation of Wildlife and People Participation), State Forest Department, Rajasthan.

Bates, P.J.J., D.L. Harrison and M. Muni (1994a). The bats of western India, Revised Part 1. Journal of the Bombay Natural History Society 91(1): 1-15.
Bates, P.J.J., D.L. Harrison and M. Muni (1994b). The bats of western India, Revised Part 2. Journal of the Bombay Natural History Society 91(2): 224-240.

Bates, P.J.J., D.L. Harrison and M. Muni (1994c). The bats of western India. Revised Part 3. Journal of the Bombay Natural History Society 91(3): 360-380.

Gupta, S. (1987). Rajasthan District Gazetteers, Jaipur.

Joshi, P. (1984). The environment limitations and future of the Asiatic Lion. Journal of the Bombay Natural History Society 81(3): 648-664. Nameer P.O. (1998). Checklist of Indian Mammals. Kerala Forest Department (Wildlife wing) and Kerala Agricultural University, 90+xxvpp.

Prakash, I. (1994). Mammals of the Thar Desert. Scientific Publisher, Jodhpur .

Prakash, I. (1995). Ecology and Zoogeography of mammals. In: R.K. Gupta and I. Prakash (editors). Environmental Analysis of Thar Desert. English Book Depot, Dehradun, pp.448-467.

Rahmani, A.R. (1991). Present distribution of the Blackbuck Antilope cervicapra Linn. in India, with special emphasis on the lesser known populations. Journal of the Bombay Natural History Society 88(1): $35-46$.

Rana, B.D. (1991). Occurrence of Bandicota bengalensis and Vandeleuria oleracea in western Rajasthan. Journal of the Bombay Natural History Society 77(3): 501.

Rice, C.G. (1991). The status of Four-horned Antelope Tetracerus quadricornis. Journal of the Bombay Natural History Society 88(1): 63-66.

Sankaran, R. (1992). Inside the Thar Desert. Sanctuary 12(2): 1627.

Sankhala, K. (1979). Tigers in the wild. Their distribution and habitat

Table 3. Recently reported mammals in Rajasthan

\begin{tabular}{lllll}
\hline Name of species & Common name & Present distribution & Census & \\
\hline Prionailurus rubiginosus & Rusty-spotted Cat & Udaipur, Sariska (Alwar) & N.A & N.A \\
Kerivoula picta & Painted Bat & Tarapur (Alwar) & N.A & N.A \\
Petaurista petaurista & Large Brown Flying Squirrel & Sitamata Wildlife Sanctuary & N.A & N.A \\
Moschiola meminna & Mouse Deer & Southern Rajasthan & N.A \\
Plantanista gangetica & Gangetic Dolphin & Chambal River (Karauli- Dholpur area) & N.A \\
\hline
\end{tabular}


Table 4. Locally extinct mammals of Rajasthan

\begin{tabular}{|c|c|c|c|c|}
\hline Name of species & Common name & Previously distributed & $\begin{array}{l}\text { Census } \\
1999\end{array}$ & 2000 \\
\hline Axis procinus & Hog Deer & Once reported from KNP (Saxena, 1975) & N.A & N.A \\
\hline Panthera leo & Lion & $\begin{array}{l}\text { Whole Rajasthan (this species was present in Jodhpur and Mt. Abu) } \\
\text { Blanford (1888-98) }\end{array}$ & N.A & N.A \\
\hline Acinonyx jubatus & Cheetah & $\begin{array}{l}\text { This species was fairly common in the vicinity of Jaipur } \\
\text { Storendole (1884) }\end{array}$ & N.A & N.A \\
\hline Equus onager & Asiatic Wild Ass & Jalore, Bikaner, Jodhpur, Jaisalmer & N.A & N.A \\
\hline Rhinoceros unicornis & Great Indian One-horned Rhinoceros & Kali Banga (Ganganagar 3500-400BC) & N.A & N.A \\
\hline
\end{tabular}

preference. Cheetal 20: 2-3.

Saxena, V.S. (1975). A Study of Flora and Fauna of Bharatpur Bird Sanctuary.

Singh, L.A.K. and R.K. Sharma (1985). Gangetic Dolphin, Platanista gangetica: Observation and habits and distribution pattern in National Chambal Sanctuary. Journal of the Bombay Natural History Society 82(3): 648-653.

Singh, Y.P. (1980). Further observation on the field ecology of Rajasthan bats. Journal of the Bombay Natural History Society 77(3): 465-470.

Sharma, S. (1995). Manis crassicaudata (Ant-eater). Rajasthan Patrika $30^{\text {th }}$ October, p. 9
Tehsin, R. (1980). Occurrence of Large Brown Flying Squirrel and Mouse Deer. Journal of the Bombay Natural History Society 77(3): 498.

Tehsin, R. (1987). The Wolf (Canis lupus) of Mewar region. Journal of the Bombay Natural History Society 84(2): 422-424.

Tripathi, J.C., V. Khanna and R.N. Chopra (1985). A list of carnivorous mammals of India. Cheetal 26(3 \& 4): 12-21.

Wada, K. (1984). Rhesus monkey distribution in the lower Himalaya and secondary forest succession. Journal of the Bombay Natural History Society 81(2): 355-363.

Table 5. Probable future invaders

\begin{tabular}{|c|c|c|c|c|}
\hline \multirow[t]{2}{*}{ Name of species } & \multirow[t]{2}{*}{ Common name } & \multirow[t]{2}{*}{ Probable future invader } & \multicolumn{2}{|c|}{ Census } \\
\hline & & & 1999 & 2000 \\
\hline Bandicota indica & $\begin{array}{l}\text { Large Bandicoot } \\
\text { Rat }\end{array}$ & $\begin{array}{l}\text { Due to increase in irrigation this species has probably reappeared in the command area } \\
\text { and is likely to extend in whole IGNP* area }\end{array}$ & N.A & N.A \\
\hline Parnechinus hypomelas & - & It is confined to Pakistan and is likely to occur in border area. & N.A & N.A. \\
\hline
\end{tabular}

IGNP* = Indira Gandhi Nahar Pariyogna 